\title{
Reconsidering the Interpretation and Dating of Ancient Coins: The Case of Bronze Coins from Dodona in the Name of Menedemos Argeades
}

\author{
Atalante BETSIOU*
}

Numismatic studies on the coin production of ancient Epirus and Corinthian colonies in Illyria have made visible progress over recent years. A contribution to the chronology of the bronze coinage of Apollonia and Dyrrhachium is due to the scholars S. Gjongecaj and O. Picard ${ }^{1}$, while G. Petrányi has undertaken the study of silver denominations ${ }^{2}$.

Despite this progress, however, the monograph of P. R. Franke, 'Die antiken Münzen von Epirus' (1961), still remains a fundamental reference guide. In his monograph, Franke succeeded, without stratigraphic data, in presenting a comprehensive publication about large quantities of numismatic material from different parts of Epirus and especially from the sanctuary of Dodona.

From the late $5^{\text {th }} \mathrm{c}$. BC the sanctuary of Dodona became the political center of the local tribes in Epirus, and under its authority a mint was established. This mint was productive during five periods, described by Franke: a) from the early $4^{\text {th }}$ c. BC until 330 BC, minting silver and bronze issues in the name of the Molossian tribe; ${ }^{3}$ b) 330-234 BC, for a wider political league, the Epirote Alliance; c) 234-168 BC, for the members of the Epirote League; d) 168-148 BC, when a series of heavy bronze issues was minted under the supervision of the priest Menedemos Argeades; and e) after $148 \mathrm{BC}$ for the last emissions of the Epirote League. ${ }^{4}$

The present paper focuses exclusively on the heavy bronze issues of Dodona, which according to Franke's dating proposal, were minted after the battle of Pydna (168 BC) and before the formation of the Roman province of Macedonia (148 BC). Due to the lack of archaeological data, Franke tried to develop dating criteria based mainly on historical considerations, although he himself expresses

*Atalante Betsiou, G. Papandreou 40, Thessaloniki, Greece (atalantib@hotmail.com).

I am greatly indebted to Prof. Katerini Liampi for her encouragement and guidance contributing to the achievement of this publication. I express my gratitude to Prof. Pantelis Nigdelis and Prof. Johannes Nollé for their remarks over matters of ideology throughout the $2^{\text {nd }}-1^{\text {st }}$ centuries $B C$ including bibliographical references. Thanks are also due to Alexandros Andreou and the Numismatic Museum of Athens for allowing me to publish the photos of Type A, and the offices of Numismatica Ars Classica, Classical Numismatic Group, Gemini Numismatic Auctions and Nomos AG for granting me the permission to use photos of coins from their auction catalogues and sites. Many thanks to Charlotte Roueché for checking the English of my text.

${ }^{1}$ Gjongecaj - Picard 2000, 137-160; Gjongecaj 2007, 55-70.

2 Petrányi 2013, 77-86 (with bibliographical references).

${ }^{3}$ Apart from the sanctuary of Dodona, Franke $(1961,92)$ has proposed that the mint of the Molossian tribe could have been established either on the site of Passaron, or Phanote.

${ }^{4}$ There is also one bronze coin, dated to the time of Hadrian, but this is beyond the scope of the present paper. For the coin, see Franke 1961, 35. 
some reservations. ${ }^{5}$ It seems certain that the sanctuary of Dodona is the provenance of these coins, as the majority of them were found during excavation work in Dodona, one in Kassope and two in a fortified villa of Dobër (Chaonia). ${ }^{6}$ However, given the limited number of obverse dies and the lack of hoard evidence, only a narrow chronological span for the circulation of these coins is plausible, as Franke has convincingly shown. ${ }^{7}$

In this paper, a different dating and historical context for these coins will be proposed, based on stylistical, epigraphical and metrological observations.

\section{Catalogue}

According to Franke's catalogue, there are three types of bronze issues (Pl. 0. 1-2)

\section{Type A}

Obv. Bust of Zeus Dodonaeus with oak wreath to the right, MENE $\triangle \mathrm{HMO} \Sigma$ IEPEY $\Sigma$.

Rev. Standing eagle, АРГЕA $\triangle \mathrm{H} \Sigma$, in oak wreath.

Franke 1961, 37, n. 1; Numismatic Museum of Athens (NM 1903), 7.745 gr.

\section{Type B}

Obv. Bust of Artemis with stephane, bow and quiver on the shoulder to the right, MENE $\triangle H M O \Sigma$ IEPEY $\Sigma$.

Rev. Arrow and quiver, АРГЕА $\triangle \mathrm{H} \Sigma$, in laurel wreath.

Franke 1961, 37, n. 5.

\section{Type C}

Obv. Bust of Zeus Dodonaeus with oak wreath to the right, АРГЕА $\triangle \mathrm{H} \Sigma$.

Rev. Bust of Artemis with stephane, bow and quiver on the shoulder to the right, MENE $\triangle \mathrm{HMO} \Sigma$ IEPEY $\Sigma$.

Franke 1961, 38, n. 9; CNG, Auction 64, 24 Jun 2003, lot 104.

\section{Iconography and style}

The repertoire of this substantial coinage follows traditional types minted from the last quarter of the $3^{\text {rd }} \mathrm{c}$. BC and downwards ${ }^{9}$. The bust of Zeus Dodonaios and his eagle or his thunderbolt within an oak wreath, together with Artemis the huntress and her attributes (bow, quiver, arrow) became the dominant subjects in the monetary iconography of the Epirote League (234-168 BC). Coin images showing Zeus were minted over a longer time, as the Epirote League used them for their emissions after $148 \mathrm{BC}$ (Pl. 0.5). The depiction of Zeus Dodonaios can be easily linked with this coin production, as these coins for the Epirote League were minted in the sanctuary of Dodona ${ }^{10}$. The

\footnotetext{
${ }^{5}$ Franke 1961, 31.

${ }^{6}$ Franke 1961, 34; Çondi 2013, 416.

${ }^{7}$ Franke 1961, 31.

${ }^{8}$ For the depiction of type B, Franke 1961, Pl. 2, V 2-R 5.

9 These types were first used on coins of the Epirote Alliance (330-234 BC), but with a different style, Franke 1961, 118-119, 121.

${ }^{10}$ Franke 1961, 32.
} 
occurrence of Artemis on these coins is likewise grounded in the popularity of this goddess' local cult among the Epirote tribes and in the neighbouring Corinthian colonies ${ }^{11}$. This cult began in the $3^{\text {rd }} \mathrm{c}$. BC and reached its peak during the following centuries; bronze specimens from the Epirote Alliance $^{12}$, Phoinike ${ }^{13}$, Apollonia ${ }^{14}$, Dyrrhachium ${ }^{15}$, and Amantia ${ }^{16}$ testify to this.

Type A, C

Zeus Dodonaios

The same obverse type of Zeus, albeit with a deteriorating style, is used, as Franke has convincingly shown, during the following period, 168-148 BC, at mints in western Greece, such as Dodona, Pandosia and Phoinike ${ }^{17}$. Whilst we can observe iconographic affinities, a stylistical resemblance is questionable. On bronze issues of Phoinike and Pandosia the depiction of Zeus retains some features of the late hellenistic style of the $2^{\text {nd }} \mathrm{c}$. BC. Also the bust of Zeus Dodonaeus on bronze coins of the Epirote League minted after $148 \mathrm{BC}$ (Pl. 0.5) should be seen in the same stylistic context. The most striking features of his face are the heavy eyebrows, the fleshy lips, the well-shaped nose and the full cheeks. On the bronze issues of Pandosia ${ }^{18}$ and the Epirote League (Pl. 0. 5) the laurel wreath emerges from the long wavy curls clearly and conspicuously, and the hair on the top of the head is divided into voluminous locks, an iconographic feature which is very unlike the dull continuous lines of the Dodonean example (Pl. 0. 1, 0.2).

During the $1^{\text {st }} \mathrm{c}$. BC, we can observe a gradual deterioration in the style of Greek mints, which present more affinities to Roman types. Coins from Dodona (Pl. 0. 1-2), Korkyra, 229-48 BC (Pl. 0. 6), and Phoinike, dated to 44-27 BC, bear a close resemblance to the Poseidon-Neptune silver denarius struck in the name of Lucius Staius Murcus, $42-41$ BC, (Pl. 0. 7) ${ }^{19}$. Gods are depicted with a statuesque facial expression, which is 'suppressed' under a massive beard and a blurred maze of hair on the shoulder. The lack of coherence is obvious as the beard is divided by a net of horizontal and vertical lines producing an unnatural look, a feature that it has in common with a contemporary bronze coin of Korkyra, 229-48 BC ${ }^{20}$. This dissolution of design is typical of coins from Dyrrhachium and the Thessalian League, which are dated after the middle of the $1^{\text {st }} \mathrm{c}$. BC (Pl. 0. 8-9).

\section{Type A (reverse)}

\section{Eagle within oak wreath}

The standing eagle within an oak wreath on the reverse type of Dodona provides a further strong indication for a later dating. On the Dodonean specimen, the eagle appears still in a rigid posture and there is no thunderbolt under his claws (Pl. 0.1). Its style differs from the preceding type of the

\footnotetext{
${ }^{11}$ Pliakou 2010, 415-419.

${ }^{12}$ See above ref. 9.

${ }^{13}$ Gjongecaj 2005, Pl. 10.2, n. 239, 242.

${ }^{14}$ SNG München 325.

${ }^{15}$ Gjongecaj 2007, 56.

${ }^{16}$ Gjongecaj 1977, Pl. II. 16.

${ }^{17}$ Franke 1961, 32, 108, 114.

${ }^{18}$ Franke 1961, Pl. 11, V 2-R 3.

${ }^{19}$ Gjongecaj 2005, 171, n. 243.

${ }^{20} \mathrm{Mc}$ Clean coll. 5253.
} 
Epirote League, 234-168 BC (Pl. 0. 3). The proportions of the body and its feathering lacking any details are similar to examples from Dyrrhachium, Lacedaemon (minted at the time of Lucius Sempronius Atratinus), and Byllis (Pl. 0. 10-12) ${ }^{21}$. The bronze issues of Dyrrhachium and Lacedaemon are dated, based on hoard evidence and historical testimonies, after the middle of the $1^{\text {st }} \mathrm{c}$. BC (38$30 \mathrm{BC}$ and 38-37 BC respectively ${ }^{22}$, while the date of the other two coins is controversial. The type of Byllis is dated to 268-168 BC according to Ceka, or 234-168 BC according to Cabanes ${ }^{23}$, but I think that the style is reminiscent of the bronze specimen from Dyrrhachion.

The version of the oak wreath on the reverse type of Dodona echoes the subtractive tendencies of the last century BC. The long jagged oak leaves are drawn in a vague way. In the Epirote (Pl. 0. 3, 0. 5) and Macedonian (Pl. 0. 14) iconography of the $2^{\text {nd }} \mathrm{c}$. BC such trends of mannerism are dominant $^{24}$.

\section{Artemis}

Additionally, we can discern stylistical differences between the Artemis types of Dodona (Pl. 0. 2) and Phoinike ${ }^{25}$, which are considered by Franke to be contemporaries, dating to 168-148 BC. Specifically, the hairstyles present stark differences. On the bronze coins of Phoinike as well as on a type of the Epirote League (Pl. 0. 4) the hair of the goddess is gathered at the back of the head in a triangular krobylos, according to the Greek manner, but in the case of Dodona (Pl. 0. 2) it is agglomerated on the top of the head, pinned from each side. A different hairstyle is also depicted in the case of Artemis Tauropolos on silver tetradrachms of the First and Second Region of Macedonia, dated after $168 \mathrm{BC}\left(\mathrm{Pl}\right.$. 0. 13-14) ${ }^{26}$.

Similar examples to the type of Dodona appear on silver tetrobols of Massalia from the first half of the $2^{\text {nd }}$ century BC (Pl. 0. 15). However, the execution of the locks and the three-dimensional depiction of the goddess are inconsistent with the style of the Dodonean coins. Emphasis on perspective also characterises the bust of Artemis Tauropolos on specimens from Pantikapaion minted during the turbulent period of Mithridates Eupator, 95-86 BC (Pl. 0. 16) ${ }^{27}$.

Apart from commercial exchanges, hoards of Roman silver denarii were found along the IllyrianEpirotic peninsula from Apollonia to Preveza. These hoards mainly contain denarii of the late republican period $\left(1^{\text {st }} \mathrm{BC}\right)$; they were buried during the Roman civil wars. Among those denarii, the

\footnotetext{
${ }^{21}$ The type of eagle is depicted on the bronze issue of Thessaloniki, dated in the imperial period from the time of Augustus till Gallienus, but its style is diminishing: SNG ANS Macedonia 807; Touratsoglou 1993, pl. X.14.

${ }^{22}$ For the date of the late bronze coin production of Dyrrhachium, Gjongecaj 2007, 55-58; RPC I 1101.

${ }^{23}$ Ceka 1972, 124; Cabanes 1976, 385.

${ }^{24}$ For the wide spread of the oak wreath as a symbol on coins of Epirote tribes, Franke 1961, Pl. 7, V 39-R 64 / V 48-R 77 (Kassope), Pl. 13-16, V 19-R 20 / V 39-R 49, R 64-81 (Epirote Symmachia), Pl. 17-18, V 1-R 1 / V 8-R 11 (Epirote League); in the monetary iconography of Macedonian mints, SNG ANS Macedonia 94-104 (Amphipolis), 581-583 (Pella), 781-783 (Thessaloniki). The reverse type of Pandosia with the naturalistic rendering of the oak wreath is a unique example, Franke 1961, Pl. 12, V 3-R 2.

${ }^{25}$ Franke 1961, Pl. 12, V 4-6.

${ }^{26}$ For more examples from the mints of the First and Second Region of Macedonia, Prokopov 2012, 41177.
}

${ }^{27}$ For the date of these specimens, Callatay 2005, 135, tab. 10. 
reverse type of Gaius Hosidius Geta (triumvir monetalis in $68 \mathrm{BC})^{28}$ very distinctively shows the characteristic hairstyle of Artemis-Diana (Pl. 0. 17), which appears utterly 'exotic' compared with the Greek monetary iconography of the Hellenistic period ${ }^{29}$. The Dodonean issue shares a common hairstyle with the types of Geta, $68 \mathrm{BC}$ (Pl. 0. 17), of Gaius Antius Restio, $47 \mathrm{BC}$, (Pl. 0. 18) and of Titus Carisius, $46 \mathrm{BC}^{30}$. Note that the last two emissions were issued under the dictatorship of Julius Caesar (a period of supreme and unquestioned power) ${ }^{31}$.

In the post-Caesarian era, the hairstyle of Artemis gradually changes. Even though the uprising locks at the center of the head remain, the hair is gathered at the back of the head, either rolled, as in the samples from Amphipolis and Ephesus (Pl. 0.19-20) or in a triangular krobylos, as on the commemorating aureus of Octavian's victories at Naulochos against Sextus Pompey and at Actium (Pl. 0.21) $)^{32}$.

The depiction of a single symbol, arrow or quiver, within a laurel wreath on the reverse type is known from the bronze emissions of Epirote mints, but the combination of these symbols appears for the first time. The rendering of the 'triangular' leaves of the laurel wreath is closer to types of silver tetradrachms minted in Macedonia at the time of Aesillas (93-92 BC) ${ }^{33}$.

\section{Metrology}

Another unique feature of these issues of Dodona is their increased weight. According to Franke's observations, we can discern three weight-classes. The weight for class A ranges from 6.31-12.8 gr., for B 7.25 gr. and for C 10.75-18.00 gr. ${ }^{34}$. Based on these measures, Kleopatra Papaevangelou-Genakos has demonstrated that type $\mathrm{C}$ corresponds to a large module of the Korkyrean bronze weight standard, which does not exceed the weight of 15.00-18.70 gr. ${ }^{35}$.

The denominational system in Macedonia for bronze coins during the republican period has already been outlined by A. Burnett, followed by S. Kremydi-Sicilianou ${ }^{36}$. Burnett has observed that during the Second Civil war Roman officers undertook the organisation of bronze coinage produced by Greek mints into the Roman monetary system through the framework of their colonial

\footnotetext{
${ }^{28}$ Denarii of Gaius Hosidius Geta were found in hoards from the theatre of Apollonia and bay of Pantocratoros in Preveza. The first one was buried after $44 \mathrm{BC}$ and the second one was lost at sea during the sea battle of Actium, 31 BC, Gjongecaj 1981, 148, n. 108/1; Chrysostomou 1987, 35-36, 41, fig. $\Delta 5$.

${ }^{29}$ Compare examples from mints of Magna Grecia during the $4^{\text {th }}-3^{\text {rd }}$ c. BC, SNG Italy 551-4 (Neapolis). 1962-6, 1969, 1980 (Rhegium); SNG Sicily 104 (Akragas); 770-1, 779, 783 (Syracuse in the time of Agathocles and during the fourth republic, 287-283 BC); and of Greek cities and Leagues during late the $4^{\text {th }}-$ mid $2^{\text {nd }} \mathrm{c}$. BC, Liampi 2003, pl. 31-2 (Iolkos); SNG Cop. Thessaly 45-46 (Demetrias) 155-156 (Koinon of Magnetes, 197-146 BC); SNG Cop. Aetolia 8-9 (Aetolian League 279-168 BC).

${ }^{30}$ Crawford 1974, 464/8a.

${ }^{31}$ Sear 1998, 23, n. 36; 49, n. 76.

${ }^{32}$ Sear 1998, 256, n. 418.

${ }^{33}$ SNG Cop. Macedonia 1327-1330.

${ }^{34}$ Franke 1961, 37-39.

${ }^{35}$ Papaevangelou-Genakos 2013, 144-146. In the Hunterian collection (Mc Donald II, 15, n. 14) there is a unique sample of type $\mathrm{C}$, which weighs $24.8 \mathrm{gr}$.

${ }^{36}$ Burnett 2000, 92; Kremydi-Sicilianou 2007, 97.
} 
policy. In 43/2 BC the proconsul Quintus Hortensius Hortalus, appointed by Marcus Junius Brutus as praefectus coloniae deducendae for the foundation of Colonia Felix Diensis (Dion of Macedonia), struck the first bronze coins of the colony in three denominations. Their heaviest issues weigh up to 20 gr. We meet a similar practice in the case of the mint of Philippi, as Colonia Julia Philippensis, and at other important cities of Macedonia, such as Thessaloniki, Pella and Amphipolis ${ }^{37}$.

The mint of Nicopolis also occasionally produced heavy coins (20.00-24.28 gr. from the Augustan era $)^{38}$. S. Gjongecaj and O. Picard have concluded that the Roman denominational system was introduced in Apollonia after the middle of the $1^{\text {st }} \mathrm{c}$. BC, not only for silver coins, but also for bronze ones. The heavy bronze issue of the Artemis/tripod type seems to be equivalent to the Roman denomination of dupondius (10.84-18.65 gr. $)^{39}$, which also corresponds to type C of Dodona. On the Peloponnese the mint of Olympia at the same period struck double asses of a medium weight of 8.43$12.03 \mathrm{gr}^{40}$, while in Lacedaemon heavy coins were produced under the authority of Lucius Sempronius Atratinus (Pl. 0. 11) ${ }^{41}$. The weight on some bronze issues of the Thessalian League, which are dated to the pre-Augustan era and the time of Petraeos (see below), ranges between 12.92 and14.54 gr. and approaches 15 gr. at the time of Augustus ${ }^{42}$. In Korkyra, a light standard has been applied, since the weight of bronze coins does not exceed 12 gr. $^{43}$

Burnett assumes that this monetary policy was implemented by the officers of Marcus Junius Brutus, Marcus Antonius and Gaius Octavius (Octavian) ${ }^{44}$. Through the establishment of new colonies in several parts of the Greek world, Roman law, Roman currency and Roman politics gained dominance. In the preceding era, Julius Caesar was the architect of the foundation of many colonies in Spain, Gaul, Africa, Italy, Greece and Pontos from the time of his first consulship until his violent death (59-44 BC). His legacy of administration and colonization was carried on by his successors. S. Kremydi-Sicilianou suggests that, even though the foundation of Colonia Felix Diensis was accomplished under the orders of Brutus and after the assassination of the dictator, it had been orchestrated by Caesar himself $f^{45}$. Another colony of Caesar, Colonia Iulia Felix Sinope, was established by proconsul S. Rufus in 46/5 BC and struck heavy issues (16.35 gr. $)^{46}$. The same year a 'bronze' coin (in fact orichalcum) was issued in Italy (weight 14.91 gr.), for the first time since the time of Sulla,

${ }^{37}$ Kremydi-Sicilianou 1996, 145-154, 285-6; RPC I, 1509-11 (Dium of Macedonia), 1545-6 (Pella), 1551-2 (Thessaloniki), 1613 (Macedonian League), 1646-9 (Philippi); SNG ANS Macedonia 150 (Amphipolis).

${ }^{38}$ Karamesini-Oeconomidou 1975, 35; for the puzzling issue of the denominational system applied to bronze coins of Nicopolis, Calomino 2012, 108-109.

${ }^{39}$ Gjongecaj - Picard 2004, 135; SNG Evelpidis II 1712 - 1713; SNG München 326. For the standard system of the silver coins of Apollonia after the middle of the $1^{\text {st }}$ century BC, RIC I, 288.

${ }^{40}$ BCD collection, Coins of Olympia, Auction Leu 90, 10. May 2004, lot. 344.1-6.

${ }^{41}$ Grunauer-von Hoerschelmann 1988, 51, n. 88.

${ }^{42}$ SNG Evelpidis 1663; SNG München 238-240 (for coins under Petraios); Weber II, 2945.

${ }^{43}$ SNG München 685-688; SNG Evelpidis II 1997, 2002.

${ }^{44}$ Burnett 2000, 92.

${ }^{45}$ Kremydi-Sicilianou 1998, 151.

${ }^{46}$ RIC I 2107. Another specimen (15.05 gr.) in the name of S. Rufus was struck by an unidentified mint, RIC I 2155. 
under the authority of the praefectus C. Clovius and during the dictatorship of Julius Caesar ${ }^{47}$. A similar practice is implied in Suetonius' biography of Caesar, in which we are informed how Caesar seized the treasure at the Capitolium at the time of his first consulship (59 BC) and how he replaced the gold coins with gilded bronze ones of equal weight (54.3: in primo consultatu tria milia pondo auri furatus e Capitolio tantundem inaurati aeris reposuit).

Nevertheless, the monetary policy of Caesar did not prove to be totally effective ${ }^{48}$. Burnett, Amandry and Ripollès regard the resolute measures for the implementation of the Roman denominational system in Greek mints as an accomplishment of Augustus. The inscription of Pherai (SEG 28.527 ) testifies to Augustus' reforms (after $27 \mathrm{BC}$ ) aiming at a readjusting ( $\delta i o ́ \rho \theta \omega \alpha)$ of the standards of the local bronze coinage ${ }^{49}$.

\section{The legend}

On the bronze issues of Dodona, we read the name, the (royal) descent and the office of a certain Menedemos, who was from the royal house of the Argeades and a priest (of the sanctuary of Dodona): MENE $\triangle H M O \Sigma$ APГEA $\triangle \mathrm{H} \Sigma$ IEPE $\Upsilon \Sigma$. The inscription is written in the nominative case. Names in the nominative are well attested on coins of Epirote mints, e.g. on money from the Epirote League (234-168 BC) ${ }^{50}$, from Ambrakia (238-168 BC) $)^{51}$, Kassope (215-195 BC) ${ }^{52}$, as well as on issues from Apollonia, Dyrrhachium and Korkyra during the $2^{\text {nd }}$ half of the $1^{\text {st }} \mathrm{BC}^{53}$.

According to Wolfang Leschhorn, coin inscriptions bearing the names and offices-such as archon, grammateus, strategos, and priest—of influential personalities appear more and more frequently from the beginning of the $1^{\text {st }} \mathrm{c}$. BC and become very common in the time of the Late Republic ${ }^{54}$. Another reference to a priest called ПАТ[E]PINOC occurs on a limited series of coins from Phoinike in Chaonia, which were minted during the period $44-27 \mathrm{BC}^{55}$. A striking difference between

${ }^{47}$ RIC I 601; Crawford 1974, 596-7, n. 476/1a. The sons of Gnaeus Pompeius issued heavy coins during their military campaigns against Julius Caesar in 46/5 BC (Spain and Africa), Crawford 1974, n. 471, 478-9.

${ }^{48}$ Caesar's concern about the control of monetary measures is implied on the types of olla and tessera nummularia, as are depicted on silver sestertius minted in $45 \mathrm{BC}$ in Rome under the name of Lollius Palicanus, Sear 1998, n. 89.

${ }^{49}$ RIC I p. 37; the heavy standard in the bronze coins of Thessaloniki was already abandoned in the Augustan era (27 BC), Touratsoglou 1988, 97, tab. 33.

${ }^{50}$ There are references on coins of the Epirote League with names such as $\Lambda \Upsilon \mathrm{KI} \Sigma \mathrm{KO} \Sigma, \Delta \mathrm{E} \Xi \mathrm{AN} \Delta \mathrm{PO} \Sigma$, $\Lambda \mathrm{E} \Omega \mathrm{N}, \Lambda \Upsilon \mathrm{KOC}, \Delta \mathrm{EP} \Delta \mathrm{A}, \Lambda \Upsilon \Sigma \mathrm{ANIA}, \Lambda \Upsilon \Sigma \mathrm{HN}$, IППОКРАТН $\Sigma, \Gamma \Lambda \mathrm{A} \Upsilon \mathrm{KO} \Sigma, \Lambda \Upsilon \Sigma \Omega \mathrm{N}, \mathrm{A \Gamma HN,} \mathrm{M \Upsilon PTI} \Lambda$ $\Lambda \mathrm{O}$. Most of them are written in nominative form, a few of them in accusative and only one in genitive, Franke 1961, 156.

${ }^{51}$ Leschhorn 2013, 161.

52 Franke 1961, 61.

${ }^{53}$ Münsterberg 1985, 109-111. In the cases of Apollonia and Dyrrhachium, the names are written in nominative form on the obverse and in genitive on the reverse, Cabanes 1997, 115-128; Leschhorn 2013, 161; for Corcyra, SNG Évelpidis II 1973-1999.

${ }^{54}$ Leschhorn 2013, 160. See below, ref. 56.

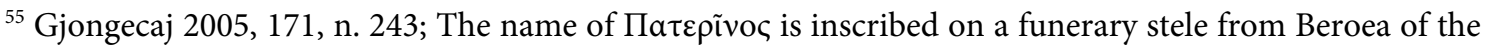
hellenistic period, and is regarded by Tataki as of Macedonian origin, see Tataki 1988, 451, 504, n. 1043. On

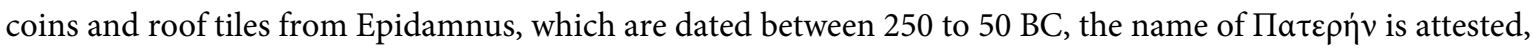


these coins and the Menedemos issues of Dodona is that on the reverses of the first ones we are confronted with the ethnicon $\Phi$ OINIKAIE $\Omega \mathrm{N}$, whereas on the Dodonean coins an ethnikon (of the citizens who minted this money) is omitted ${ }^{56}$. The omission of a civic authority is not by coincidence ${ }^{57}$. On the contrary, Menedemos has taken the place of the city, and uses all three types to present himself instead of the city's identity. It is tempting to suggest that during his priesthood as a

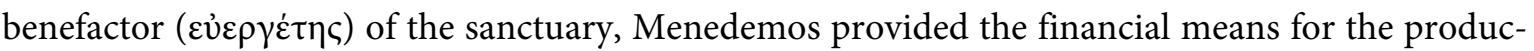
tion of these issues ${ }^{58}$.

Studying the inscription of the Dodonean coins further, Franke was the first scholar who emphasized the association of Menedemos with the Argeads, the famous royal branch from Macedonia ${ }^{59}$. The name Menedemos, in contrast to the Epirote type of Menedamos ${ }^{60}$, often appears in inscriptions from Macedonia, Thessaly (Perrhaibia, Thessaliotis, Pelasgiotis) and Attica ${ }^{61}$. There is a simple reference on a silver coin of the Thessalian League dated to a period after the middle of the $1^{\text {st }} \mathrm{c}$. $\mathrm{BC}^{62}$.

LGPN III.A, 356. The name of a priest is also inscribed on bronze issues from Pheneos, which are dated to 146-31 BC, (ЕПI IEP]EO $\Sigma$ EPMAЕOOY), BMC Peloponnesus, 36.13.

${ }^{56} \mathrm{On}$ coins of the $1^{\text {st }} \mathrm{c}$. BC there are occasionally legends with offices, such as on a sample from Thebes,

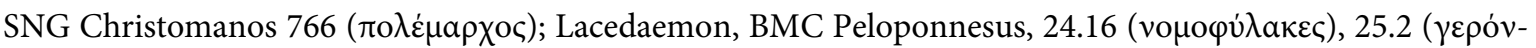

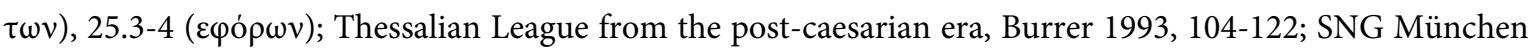

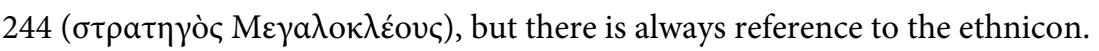

${ }^{57}$ The function of a local political Koinon, whose name is not preserved (the Epirote League?), is testified on an inscription, which was erected for the dedication of a statue of Livia within the precinct of the sanctuary of Zeus Dodonaeus. For this inscription and the significance of the sanctuary of Dodona in the Augustan era, Piccinini 2013, 184-192.

${ }^{58}$ Gaius Antonius participated as a priest of Dionysus in the festivities of the god in Dionysopolis of Thrace and he contributed financially to the distribution of meat [as epigraphic evidence testifies] (Syll ${ }^{3}$ 762).

${ }^{59}$ According to Hesiod and Appian, the Argeadae came from Orestis and moved to the district of Pieria

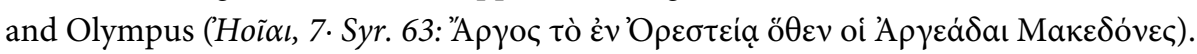

${ }^{60}$ References to Menedamus are detected on a lead tablet from Dodona (330 BC) and on an honorary decree for judges from Larissa (140-130 BC), both written under the authority of the Molossian League, SEG LIV (2004), n. 576, l. 13, SEG LVII (2008), n. 510, IV, 1. 57-58, 78-79; on an inscribed 'proedria' from the theater of Gitana $\left(3^{\text {rd }} / 2^{\text {nd }} B C\right)$, SEG LI (2001), n. 750; on a funerary stele from Apollonia (Hellenistic period), Cabanes et alii 1997, n. 119; and on a decree from the parodos of the theater of Asclepius of Buthrotum (Hellenistic period), Cabanes et alii 2007, n. 31, 1. 3-5. The popularity of this name is apparent in Western Greece, Southern Italy and some parts of Thessaly (Pelasgiotis), LPGN IIIA-IIIB, 1. Menedamus.

${ }^{61}$ For an approach to the prosopography of ancient Macedonia, Tataki 1998, 367; LPGN IIIB-IV, 1. Menedemos. On attic funerary steles and tetradrachms of new style, the name Menedemos is attested 26 times from $475 \mathrm{BC}$ till $1^{\text {st }}$ c. AD and Menedamos only once, LPGN II, 1. Menedemos. Thompson 1961, 573. The name of Menedamos appears on a silver issue of Aenianes dated to the $1^{\text {st }} \mathrm{c}$. BC, Roma Numismatics, e-Auction 23, 9 January 2016, lot. 60 .

${ }^{62}$ SNG München 207. 
Franke had suggested that Argeades could have been the name of Menedemos' father ${ }^{63}$. Nevertheless, documentary evidence in epigraphic studies that would support such an interpretation, is totally lacking. Moreover, Argeades as a personal name is very rare and is attested only twice (Attica in $510 \mathrm{BC}$ and Daulis of Phokis in the $2^{\text {nd }}$ c. BC). ${ }^{64}$. By minting his name on these coins, Menedemos presented himself as a descendant of the old Macedonian royal house and as a priest of one of the most distinct sanctuaries of Greece. Menedemos is presented not as the son of Argeades, but as an Argead, i.e. a descendant of the Argeads ${ }^{65}$.

A striking characteristic of this series is the placing of the coin inscription on the reverse of denomination C. The letters are inscribed vertically along the bust of Artemis, in this way forming a framework. In the previous coin issues of the Epirote League (234-168 BC), personal names are exclusively positioned around the border of the coins ${ }^{66}$. On the other hand, in the monetary history of Macedonia since the times of Alexander the Great we can find many examples of the vertical orientation of coin inscriptions, e.g. for Alexander himself and his successors Kassander, Lysimachos, Demetrios Poliorketes until Philip V. Their names are vertically inscribed on the reverses ${ }^{67}$. It may be that the Argead Menedemos, following the traditions of his royal ancestor on the obverse of Dodonean large specimens, had the 'royal' name fully inscribed along the face of Zeus (Pl. 0. 2).

\section{Historical background}

A year after the victory of Lucius Aemilius Paulus over Perseus at Pydna (168 BC), Roman legions marched into Epirus. On the orders of the Roman Senate, 70 cities were ransacked, most of them in Molossis, and 150,000 people were enslaved, according to the testimonies of Polybius (30.15.1), Livius (45.34.5-6) and Plutarch (Paulus 29.3).

With the downfall of the southern Epirote cities, Phoinike, a new political center from Chaonia, arose. Charops the Younger managed to establish his authority in the city and gained political power with the tolerance of Rome. Furthermore, he used proscriptions against wealthy co-citizens in order to execute or exile them and to come into possession of their properties. His atrocities, described vividly by Polybius (32.20-1), continued at Brundisium until his death in the years between 159-157 BC. In the following year (157/6 BC), the Senate accepted the embassies of two separate leagues from Epirus, the first from Phoinike and the second from the remaining part, referred to by

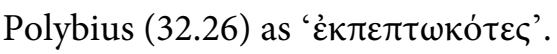

\footnotetext{
${ }^{63}$ Franke 1961, 308. Inscriptions on coins bearing name and patronymic are not so frequent, with the exception of a rare series of silver denarius minted in Apollonia after the middle of $1^{\text {st }} \mathrm{c}$. BC. On the obverse type is depicted the radiate bust of Apollo-Helios surrounded by an inscription bearing the name and the patronymic in genitive form (ANTIOXOY TOY BAKXI $\triangle$ OY), SNG Cop. Thessaly-Illyricum 404.

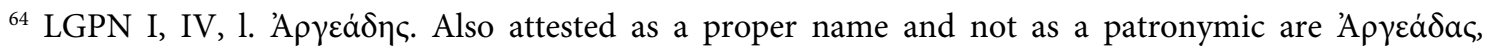

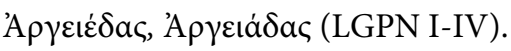

${ }^{65}$ For similar examples of honours for persons of royal descent, Quaß 1993, 74.

${ }^{66}$ Franke 1961, Pl. 24-28, V 79-87B, V 95, 101-102A, 108-9, 125-132.

${ }^{67}$ SNG Cop. Macedonia 1163 (Kassander), 1164 (Lysimachus), 1176 (Demetrios Poliorcetes); Touratsoglou 1993, Pl. 2.2-8 (Philip V). The names of the Kings Alexander of Neoptolemos and Pyrrhos are applied in a similar fashion on coins minted in Italy and Sicily during their glorious military campaigns (334-331 BC, 280-275 BC), SNG München 596-597, 609-619.
} 
The second half of the $2^{\text {nd }}$ century $\mathrm{BC}$ was marked by the insurrection of Philip IV Andriscus, which broke out in Macedonia in 149 BC, and the destruction of Corinth (146 BC). This political instability demonstrated the necessity of improving administration and led finally to the formation of the Roman provinces. Macedonia, the wealthiest of these newly created administrative units, was extended to the Adriatic coast, thus including Epirus. In this period, as it is attested by the honorary monument for the wrestler Menodoros (146-130 BC) ${ }^{68}$, the sanctuary of Dodona remained prosperous and organized brilliant as well as costly festivities with panhellenic athletic contests, the Naia. In the summer of 88 BC Thracian mercenaries of Mithridates VI Eupator invaded Macedonia and plundered the sanctuary of Zeus in Dodona, as Dio Cassius testifies (101.2).

In his correspondence, Cicero narrates his exile from Rome and his wandering to Dyrrhachium in 58 BC (Epist. ad fam., 14.1.7). In the next year, recalled from exile, he returned to Rome, where he castigated the horrible misgovernment of L. Calpurnius Piso Caesoninus in the province of Macedonia in his speeches. According to his accusations, Piso plundered Ambrakia and drove the cities of Dyrrhachium and Apollonia to financial prostration (In Pisonem, 91, 96, Pro Sestio 94). In the end, Cicero achieved Piso's suspension from the administration of the province of Macedonia in 55 BC. Due to Piso's suspension, he became so popular among the citizens of Dyrrhachium that Brutus requested his mediation for a financial dispute, in which their common friend, Flavius, was involved (1.6.4).

The second half of the $1^{\text {st }} \mathrm{c}$. BC was a turbulent period of political conflicts, which was inaugurated by the outbreak of the Civil War between Caesar and Pompey (48 BC). The war took place in Epirus and Thessaly, and led to Greek cities backing different sides. Appian's narrative recounts how the city of Apollonia opened the gates to the veterans of Julius Caesar, whilst Dyrrhachium became

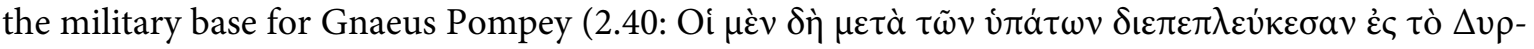

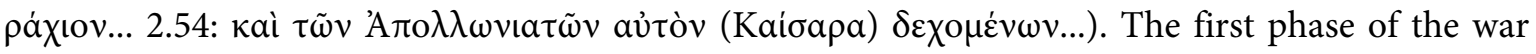

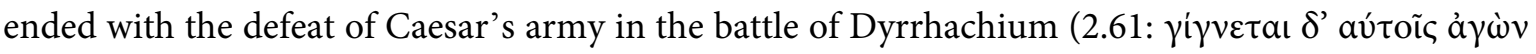

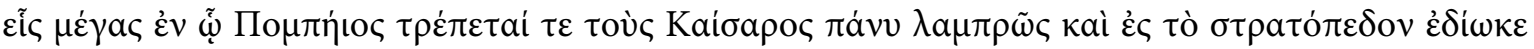

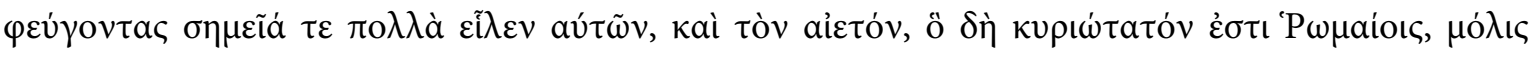

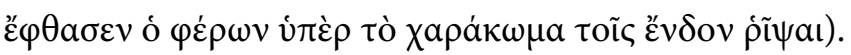

During the military preparations for the battle of Pharsalos, both armies were reinforced, as Appian

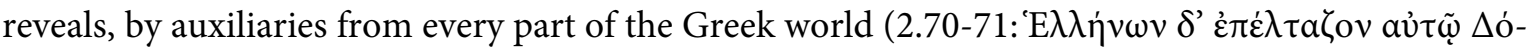

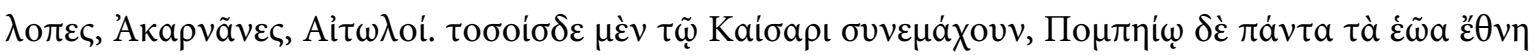

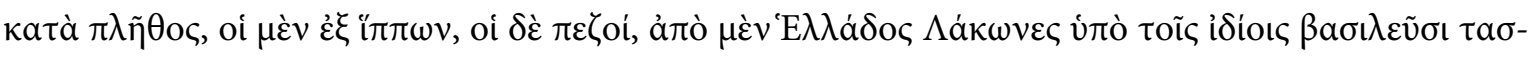

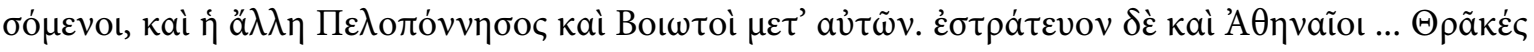

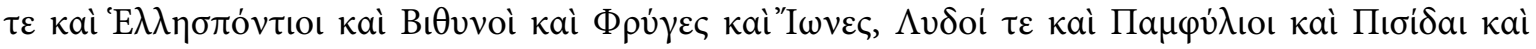

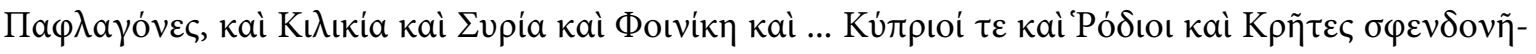

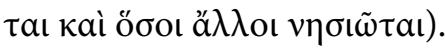

In his Civil Wars, Julius Caesar makes brief references $(3.34 .2,3.35 .2)$ to his most important supporters, Menedemos from Macedonia (libera), the supreme leader of the area, and Petraeus from Thessaly, who promised to assist him against Pompey $(48 \mathrm{BC})^{69}$ : ...in Macedoniam... cuius provinciae ab ea parte, quae libera appellabatur, Menedemus, princeps earum regionum, missus legatus

\footnotetext{
${ }^{68}$ Dow 1935, 81-90.

${ }^{69}$ Batstone-Damon 2006, 138.
} 
omnium suorum excellens studium profitebatur... Petraeus, summae nobilitatis adulescens, suis ac suorum opibus Caesarem enixe iuvabat.

Caesar's victory in the battle of Pharsalus ${ }^{70}$ brought his rise to autocracy. His assassination in $44 \mathrm{BC}$ triggered new political rivalries between the Caesarians and the so-called Liberatores. Driven by the new political instability, the Senate reluctantly assigned the administration of the province of Mac-

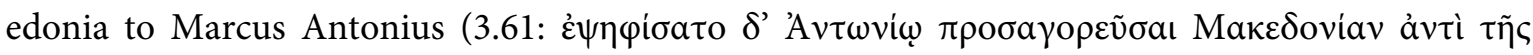

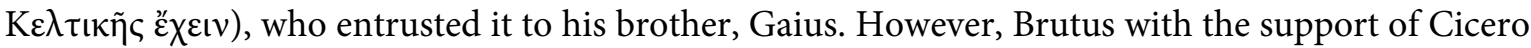

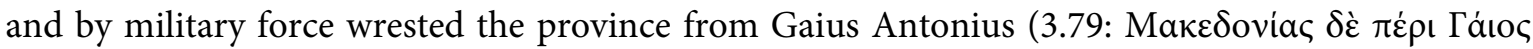

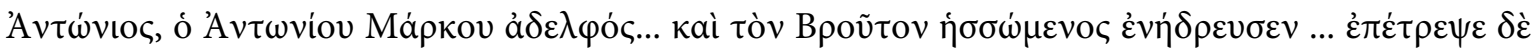

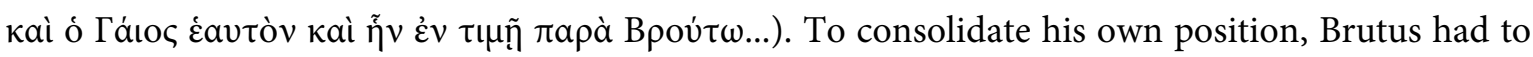
pursue and exterminate the strongest supporters of the Caesarians in the Eastern provinces from Macedonia to Syria. To this end he tried to gain absolute control over their financial resources and

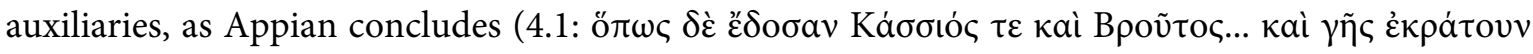

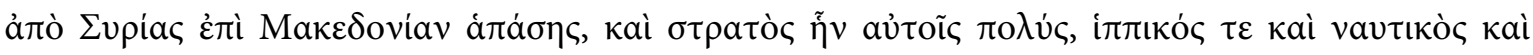

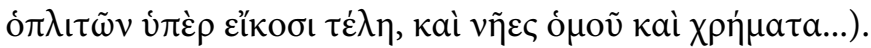

In the course of the proscriptions of the Triumvirate Cicero was executed in 43 BC (4.20: ó $\delta \dot{\varepsilon} \Lambda a i ̈-$

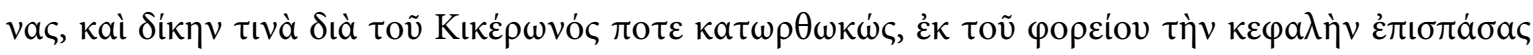

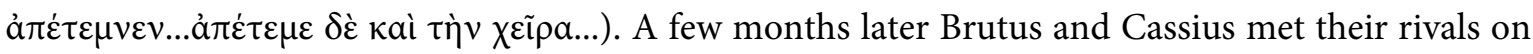
the battlefield of Philippi. After their total defeat, Brutus appealed to his friend Straton from Epirus

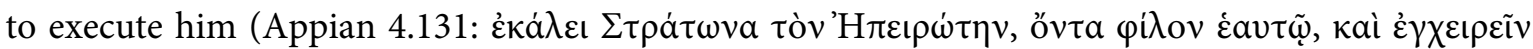
$\dot{\varepsilon} \kappa \dot{\varepsilon} \lambda \varepsilon v \varepsilon \tau \tilde{\omega} \sigma \omega \dot{\omega} \mu \alpha \tau)$.

The outcome of the naval victory of Actium in $31 \mathrm{BC}$ made Octavian the indisputable founder of Pax Romana. Nevertheless, peace had not yet been established.

\section{Historical identity of Menedemos}

The identity of Menedemos Argeades still remains unclear. Caesar refers to Menedemos from Macedonia libera (i. e. the western part) ${ }^{71}$ and Petraeos from Thessaly as his supporters before the battle of Pharsalos. According to Münzer, Menedemos from Macedonia, the supporter of Caesar, is the same person mentioned by Cicero three times in his correspondence with Atticus (15.2.2, 15.4.4, 15.19.2) and once in the $13^{\text {th }}$ Philippicus $(13.33)^{72}$ : de Menedemo probe... de Menedemo vellem verum fuisset, de regina velim verum sit...de Menedemo est ut scribis... Securi percussos Petraeum et Menedemum civitate donatos et hospites Caesaris laudastis.

\footnotetext{
70 The defeat of Gnaeus Pompeus was attributed by M. Annaeus Lucanus in his poem to Sextus' defiance to consult the oracles of Delos, Delphi and Dodona before the battle (Pharsalia, 6.424-6: Impatiensque morae, venturisque omnibus aeger, Non tripodas Deli, non Pythia consulit antra, Nec quaesisse libet, primis quid frugibus altrix Aere Iovis Dodona sonet.).

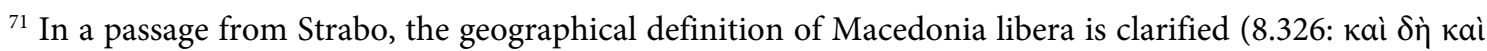

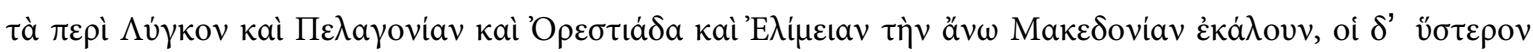
кaì $\dot{\varepsilon} \lambda \varepsilon v \theta \dot{\varepsilon} \rho a v)$. It should be noted that the Argeades came from the same part of Macedonia, according to

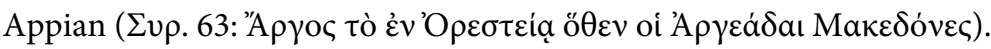

${ }^{72}$ RE XV, Menedemus, col. 787 - 8, n. 6 (F. Münzer).
} 
Cicero is revealingly hostile to Menedemos. Menedemos was an intimate follower of Caesar (hospes Caesaris) ${ }^{73}$ and granted the privilege of Roman citizenship. Due to his political intimacy with the dictator, he faced the enmity of the anti-Caesarian coalition, which resulted in his execution together with Petraios by Brutus in 44/43 BC. In the case of Petraios, numismatic evidence (Pl. 0.10) confirms his major political significance as strategos of the Thessalian League during the years 49/8-44 $\mathrm{BC}^{74}$.

The expression 'princeps earum regionum' (Macedonia) used by Caesar of Menedemos also indicates a prestigious political personality, possibly even hinting at royal descent. Menedemos' Macedonian origin would not have been an obstacle for becoming a priest of the sanctuary of Dodona. A few years later Augustus assigned the supervision of the Actian games at Nicopolis to the Lacedae-

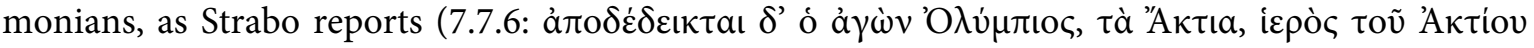

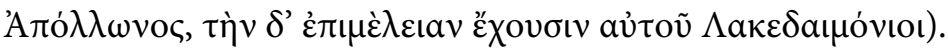

The high esteem for royal descent further adds to this picture. ${ }^{75}$. Kings or notables of royal ancestry were already highly valued by Julius Caesar and later by his adopted son, Augustus; an Argead would have been a welcome ally. ${ }^{76}$

\section{Conclusions}

Numismatic parameters, including stylistic comparisons and metrological observations, suggest a date for these issues after the $2^{\text {nd }}$ half of the $1^{\text {st }} \mathrm{c}$. BC. The gradual decline of style is evident across all the types, which are products of clumsy and inaccurate work, typical of this period.

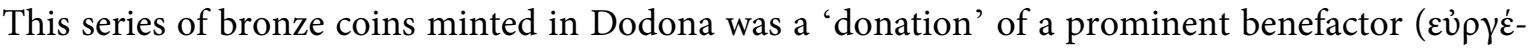
$\tau \eta \varsigma$ ) from Macedonia. The promotion of the personality of Menedemos in his exceptionally large inscription, which monopolizes both sides of these coins reflects the values of this period (dictated by mos maiorum), when distinguished ancestry was the fundamental stepping-stone for political elevation. Epigraphic and literary testimonies indicate that this donor should be identified with a man prominent in the region in the same period. A man of action, he benefitted from his intimate political friendship with Julius Caesar (48 BC), a bond which cost him his life (44/43 BC).

The production of these issues may be linked to the functions of the sanctuary, since festivities and games took place in Dodona. It seems that in addition to the summa honoraria he paid in order to

${ }^{73}$ For the importance of hospitium as a medium of communication between the Roman and the Greek élites, Spawforth 2012, 53. For the beneficial friendship of Julius Ceasar, Quaß 1993, 143-145.

${ }^{74}$ Kramolisch, 1978, 115-117. For the date of Petraios' coin based on the hoard evidence of Aidona (Kalambaka) in 1955, Franke 1957/60, 63, 66.

${ }^{75}$ From the first quarter of the $1^{\text {st }}$ century BC, there are emissions of silver tetradrachms in Macedonia under the authority of the quaestor Aesilas with the bust of Alexander The Great as an obverse type, SNG

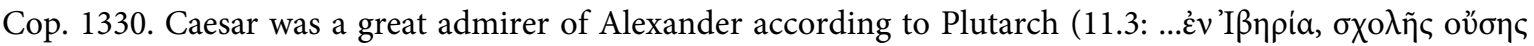

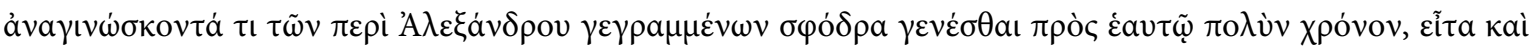

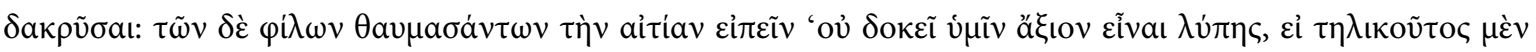

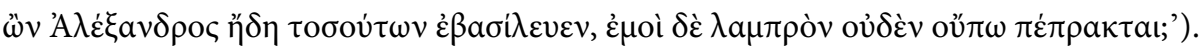

${ }^{76}$ Suetonius, Julius Caesar 2: a quo ad accersendam classem in Bithyniam missus desedit apud Nicomeden, non sine rumore prostatae regi rudicitiae... and 28: nec monire studio reges atque provincias per terrarum orbem adliciebat. For commentary on this matter at the time of Augustus, Spawforth 2012, 39. 
become a priest, Menedemos also chose to cover some expenses through minting bronze issues for the sanctuary ${ }^{77}$. For this reason, the types of coins are mainly inspired by the 'panhellenic' cult of Zeus of Dodona and of Artemis, the latter being very popular in the province of Macedonia (including Epirus) from the middle of the $2^{\text {nd }}$ century $\mathrm{BC}^{78}$.

The cult of Diana became prominent in Roman monetary iconography during the $1^{\text {st }} \mathrm{c}$. BC, reaching the highest peak of popularity in the second half of the century, ${ }^{79}$ when silver denarii were minted under the caesarians C. Antius Restio and T. Carisius, and a series of commemorating aurei for the naval victories of Augustus in Naulochos and Actium. The adoption of a theme which would be readily recognised by the Romans, for a currency which corresponded with Roman coinage, is typical of this period of adjustment to Roman dominance.

\section{Bibliography}

\section{Abbreviations}

LPGN

A Lexicon of Greek Personal Names, I. The Aegean Islands, Cyprus and Cyrenaica, (eds. P. M. Fraser - E. Matthews), Oxford 1987; II. Attica, (eds. M. J. Osborne - S. G. Byrne), Oxford 1994; IIA. The Peloponnese, Western Greece, Sicily and Magna Graecia, (eds. P. M. Fraser - E. Matthews), Oxford 1997; IIIB. Central Greece, (eds. P. M. Fraser - E. Matthews), Oxford 2000; IV. Macedonia, Thrace, (eds. P. M. Fraser - E. Matthews), Oxford 2005.

RE

SEG

\section{Numismatic Collections}

BMC Peloponnesus

Hunterian coll.

Mc Clean

RIC
Paulys Real-Enzyklopädie der Klassischen Altertumswissenschaft, Stuttgart 1931.

Supplementum Epigraphicum Graecum

P. Gardner (ed.), Catalogue of Greek coins from British museum, Peloponnesus, London 1887.

G. Mc Donald (ed.), Catalogue of Greek coins in the Hunterian collection of the University of Glasgow, Glasgow 1901.

S. W. Grose (ed.), Catalogue of the Mc Clean Collection of Greek Coins, vol. II, The Greek Mainland, The Aegean Islands, Crete, Chicago 1979.

A. Burnett - M. Amandry - P. P. Ripollès, Roman Provincial Coinage, Vol. I, From the Death of Caesar to the Death of Vitellius

${ }^{77}$ For the payment of summa honoraria, Sartre 1997, 121.

${ }^{78}$ In the same period Roman deities, such as Dea Roma, Zeus Eleutherios and Janus, are depicted on the bronze coins of the mints of Macedonia, such as Pella, Amphipolis and Thessaloniki, Liampi 2002, 215-218, Touratsoglou 1993, tab. X.5-6, XI.14. For the depiction of Roma in ancient art during the late Hellenistic and Republican era, Gounari 2003, 24-33.

${ }^{79}$ The Artemis-Diana type appeared on the Roman silver denarius for the first time only at the beginning of the $1^{\text {st }}$ c.BC, Crawford 1974, 335/9 (100 BC), 372/1 (81 BC), 383/1 (79 BC), 394/1 (74 BC), 407/1-2 (68 BC), 455/3 (after 50 BC), 464/8a (after 50 BC). 
RPC I

SNG ANS Macedonia

SNG Christomanos

SNG Cop. Italy

SNG Cop. Sicily

SNG Cop. Thessaly-Aetolia

SNG Evelpidis

SNG KIPKE

SNG München

SNG Soutzos

Weber II

\section{General}

Batstone - Damon 2006

Burnett 2000

Burrer 1993

Cabanes 1976

Cabanes et alii 1997
(44 B.C.-69 A.D.), Paris 1992.

A. Burnett - M. Amandry - P. P. Ripollès, Roman Provincial Coinage, Vol. I, From the Death of Caesar to the Death of Vitellius (44 B.C.-69 A.D.), Paris 1992.

SNG The American Numismatic Society, Part 7, Macedonia 1: Cities, Thraco - Macedonian Tribes, Paeonian Kings, New York 1987.

SNG Greece 3: Collection Antoine Christomanos, Athens 2004.

SNG The Royal Collection of Coins and Medals, Danish National Museum. Vol. I-III Italy: Etruria-Campania, Apulia-Lucania, Lucania-Bruttium, Copenhagen 1942.

SNG The Royal Collection of Coins and Medals, Danish National Museum. Vol. IV-V Sicily: Abacaenum-Petra, Segesta-Sardinia, Copenhagen 1942.

SNG The Royal Collection of Coins and Medals, Danish National Museum. Vol. III Greece: Thessaly-Illyricum. Epirus-Acarnania (N. Breitenstein), Copenhagen 1943. Vol. XIII, Aetolia to Euboea (N. Breitenstein), Copenhagen 1944.

SNG Grèce. Collection Réna Evelpidis, Athènes, IIe Partie: Macedoine-Thessalie-Illyrie-Épire-Corcyre (T. Hackens), Louvain 1975. SNG Greece 7, The KIPKE Collection of Bronze Coins, Vol. I, (ed. V. Penna-Y. Stoyas), Athens 2011.

SNG Deutschland, Staatliche Münzsammlung München 12. Heft, Thessalien-Illyrien-Epirus-Korkyra: Nr. 1-701 (K. Liampi), Munich 2007.

SNG Greece 5, The A. G. Soutzos Collection, (E. Tsourti - M. D. Trifiró), Athens 2007.

L. Forrer, The Weber Collection II, Greek Coins, London 1924.

W. W. Batstone - C. Damon, Caesar's Civil Wars, Oxford 2006.

A. Burnett, The Coinage of Roman Macedonia, in: P. Adam-Vele-

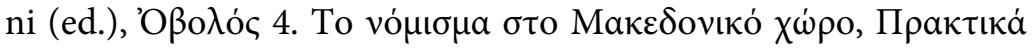

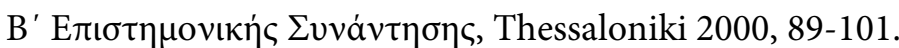

F. Burrer, Münzprägung und Geschichte des Thessalischen Bundes in der römischen Kaiserzeit bis auf Hadrian (31 v. Chr.-138 n. Chr.), Saarbrücken 1993.

P. Cabanes, L'Épire de la mort de Pyrrhos à la conquête romaine (272-167 av. J. - C.), Paris 1976.

P. Cabanes - N. Ceka - O. Masson - M. Hatzopoulos (eds.), Études Epigraphiques 2, Corpus des inscriptiones grecques d' Illyrie méridionale et d'Épire, I. Inscriptions d'Épidamne-Dyrrha- 
Cabanes et alii 2007

Callataÿ 2005

Calomino 2012

Ceka 1972

Chrysostomou 1987

Çondi 2013

Crawford 1974

Dow 1935

Franke 1957/60

Franke 1961

Gjongecaj - Picard 2000

Gjongecaj - Picard 2004

Gjongecaj 1977

Gjongecaj 1981

Gjongecaj 2005 chion et d'Apollonia, 2. Apollonia, Paris 1997.

P. Cabanes - F. Drini - M. Hatzopoulos (eds.), Études Epigraphiques 2, Corpus des inscriptiones grecques d'Illyrie méridionale et d'Épire, 2. Inscriptions de Bouthrôtos, Athens 2007.

F. de Callataÿ, Coins and Archaeology: the (Mis)use of Mithridatic Coins for Chronological Purposes in the Bosporean Area, 119-136. (article from internet, http://mithridat-eupator.ru/biblioteka/callatay2005.pdf)

D. Calomino, Actia Nicopolis. Coinage, Currency and Civic Identity (27 BC-268 AD), in: F. López-Sánchez (ed.), The City and the Coin in the Ancient and Early Medieval Worlds, Oxford 2012, 103-113.

H. Ceka, Questions de numismatique Illyrienne, Tirana 1972.

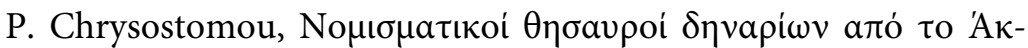

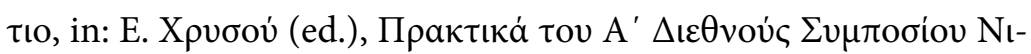

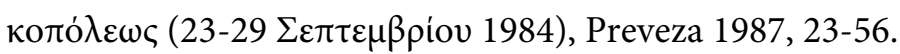

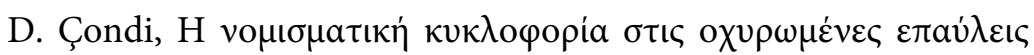

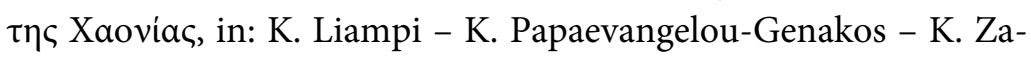
chos - A. Ntouzougli - A. Iakovidou (eds.), Numismatic History and Economy in Epirus during antiquity, Proceedings of the $1^{\text {st }}$ International Conference, University of Ioannina, $3^{\text {rd }}-7^{\text {th }}$ October 2007, Athens 2013, 411-420.

M. H. Crawford, Roman Republican Coinage, London 1974.

S. Dow, Monument to the athletic victor Menodoros, Greek inscriptions, Hesperia 4, 1935, 81-90.

P. R. Franke, Zur Chronologie der Strategen und Münzprägung des Koinon der Thessaler, Schweizer Münzblätter 7-8, 1957-60, 61-67.

P. R. Franke, Die antiken Münzen von Epirus, Wiesbaden 1961.

S. Gjongecaj - O. Picard, Les drachmes d'Apollonia à la vache allaitant, RN 155, 2000, 137-160.

S. Gjongecaj - O. Picard, Le monnayage d'Apollonia sous l'Empire Romain, in: P. Cabanes - J. L. Lamboley (eds.), L'Illyrie méridionale et l'Epire dans l'Antiquité IV, Actes du IVe Colloque international de Grenoble, Paris 2005, 134-148.

S. Gjongecaj, Les monnayage d'Amantie, Iliria VII, 1977, 100-112.

S. Gjongecaj, Un trésor de monnaies antiques provenant d' Apollonie, Iliria, 11.2, 1981, 105-152.

S. Gjongecaj, Nuovi dati numismatici da Phoinike (scavi 20012003), in: S. De Maria - S. Gjongecaj (eds.), Phoinike III, Rapporto preliminare sulle campagne di scavi e ricerche 2002-2003, Bologna 2005, 161-179. 
Gjongecaj 2007

Gounari 2003

Grunauer-von Hoerschelmann 1988

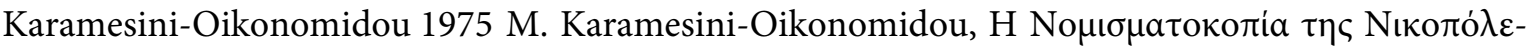

Kramolisch 1978

Kremydi-Sicilianou 1996

Kremydi-Sicilianou 1998

Kremydi-Sicilianou 2007

Leschhorn 2013

Liampi 2002

Liampi 2003

Münsterberg 1985

Papaevangelou-Genakos 2013

Petrányi 2013 $\omega \varsigma$, Athens 1975. ve (ed.), Épire, Illyrie, Macédoine, Mélanges offerts au Professeur Pierre Cabanes, Clermont-Ferrand 2007, 55-70.

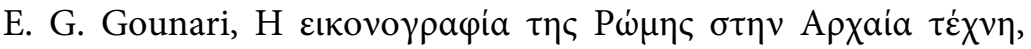
Thessaloniki 2003.

S. Grunauer-von Herschelmann, Die Münzprägung von Lakedaimonier, Berlin 1988.

H. Kramolisch, Die Strategen des Thessalischen Bundes von 196

V. Chr. bis zum Ausgang der römischen Republik, Bonn 1978.

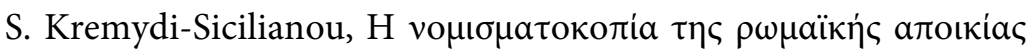

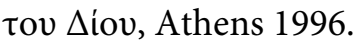

S. Kremydi-Sicilianou, Quintus Hortensius Hortalus in Macedonia (44-42 BC), Tekmeria 4, 1998, 61-76.

S. Kremydi-Sicilianou, Belonging to Rome, Remaining Greek: Coinage and Identity in Roman Macedonia, in: C. Howgego - V. Heuchert - A. Burnett (eds.), Coinage and Identity in the Roman Provinces, Oxford 2007, 96-106.

W. Leschhorn, Die "Beamtennamen" auf den Münzen von Epirus, in: K. Liampi - K. Papaevangelou-Genakos - K. Zachos - A. Ntouzougli - A. Iakovidou (eds.), KERMA III, Numismatic History and Economy in Epirus during Antiquity, Proceedings of the 1 st International Conference, University of Ioannina, $3^{\text {rd }}-7^{\text {th }}$ October 2007, Athens 2013, 159-170.

K. Liampi, Zeus Eleutherios in Makedonien, AM 117, 2002, 203220.

K. Liampi, Die Münzprägung des Makedonischen Koinon in der Kaiserzeit, in: C. Alfaro, C. Marcos, P. Otero (eds.), XIII Congresso Internacional de Numismática, Madrid 2003, 891-904.

R. Münsterberg, Die Beamtennamen auf den griechischen Münzen, New York ${ }^{2} 1985$.

C. Papaevangelou-Genakos, The Monetary Systems of Epirus, in: K. Liampi - K. Papaevangelou-Genakos - K. Zachos - A. Ntouzougli - A. Iakovidou (eds.), Numismatic History and Economy in Epirus during Antiquity, Proceedings of the $1^{\text {st }}$ International Conference, University of Ioannina, $3^{\text {rd }}-7^{\text {th }}$ October 2007, Athens 2013, 131-149.

G. Petrányi, Cow/Calf Type Greek-Illyrian Drachms: Problems and Facts, in: K. Liampi - K. Papaevangelou-Genakos - K. Zachos - A. Ntouzougli - A. Iakovidou (eds.), KERMA III, Numismatic History and Economy in Epirus during Antiquity, Proceedings of
S. Gjongecaj, Les bronzes de Dyrrachion, in: D. Berranger-Ausser- 
Piccinini 2013

Pliakou 2010

Prokopov 2012

Quaß 1993

Sartre 1991

Sear 1998

Spawforth 2012

Tataki 1988

Tataki 1998

Thompson 1961

Touratsoglou 1988

Touratsoglou 1993 the $1^{\text {st }}$ International Conference, University of Ioannina, $3^{\text {rd }}-7^{\text {th }}$ October 2007, Athens 2013, 77-86.

J. Piccinini, Dodona at the times of Augustus. A few notes, in: M. Galli (ed.), Roman Power and Greek Sanctuaries. Forms of Interaction and Communication, Athens 2013, 177-192.

G. Pliakou, III. 1. Sanctuaires de divinités féminines et culte D'Artémis en Épire centrale, BCH 134, 2010, 415-419.

I. Prokopov, The Silver Coinage of the Macedonian Regions, $2^{\text {nd }}-$ $1^{\text {st }}$ Century BC, Moneta 131, Wetteren 2012.

F. Quaß, Die Honoratiorenschicht in den Städten des griechischen Ostens. Untersuchungen zur politischen und sozialen Entwicklung in hellenistischer und römischer Zeit, Stuttgart 1993.

M. Sartre, L'Orient romain: Provinces et en sociétés provinciales en Méditerranée orientale d'Auguste aux Sévères (31 avant J.-C. 235 après J.-C.), Paris 1991.

D. R. Sear, The History and Coinage of the Roman Imperators, 4927 BC, London 1998.

A. J. S. Spawforth, Greece and the Augustan Cultural Revolution, Cambridge 2012.

A. B. Tataki, Ancient Beroea. Prosopography and Society, Meletemata 8, Athens 1988.

A. B. Tataki, Macedonians Abroad. A Contribution to the Prosopography of Ancient Macedonia, Meletemata 26, Athens 1998.

M. Thompson, The New Style Silver Coinage of Athens, New York 1961.

I. Touratsoglou, Die Münzstätte von Thessaloniki in der römischen Kaiserzeit, Berlin 1988.

I. Touratsoglou, Numismatic Circulation in Ancient Macedonia (200 BC-286 AD)- The Hoard Evidence, Athens 1993.

\section{List of coins in the Plates:}

1) Numismatic Museum of Athens, NM 1903.

2) CNG, Auction 64, 24 Jun 2003, lot 104.

3) NAC AG, Auction 54, 24 March 2010, lot. 784.

4) Triton V Sale, 15 Jan 2002, lot 340.

5) Triton V Sale, 15 Jan 2002, lot. 337.

6) CNG, Auction 61, Sep 25, 2002, lot. 208.

7) CNG, Triton XVI, 9 January 2013, lot. 926.

8) From site: http://www.wildwinds.com/coins/greece/illyria/dyrrhachium/BMC_163.txt

9) CNG, Auction 337, 22.10.2014, lot. 60. 
10) From site: http://www.wildwinds.com/coins/greece/illyria/dyrrhachium/BMC_185.txt

11) Gemini, LLC Auction X, Jan 2013, lot. 410.

12) CNG, 26 e-Auction 173, September 2007, lot. 92.

13) Gemini I, Auction Jan 11-12, 2005, lot. 99.

14) Triton XIV, Jan 4-5, 2011, lot. 97.

15) Nomos AG, Auction 10, 18 May 2015, lot. 1.

16) CNG, Auction 61, Sep 25, 2002, lot. 512.

17) NAC AG, Auction 78, 26-27 May 2014, lot. 656.

18) From site: http://www.wildwinds.com/coins/rsc/antia/antia3.jpg).

19) From site: http://www.wildwinds.com/moushmov/amphipolis.html

20) Triton V Sale, 15 Jan 2002, lot 463.

21) From site:http://www.ancientcoins.ca/RIC/RIC1/RIC1_Augustus_201-400.htm, n. 273. 


\section{Antik Sikkelerin Yorumlanmasını ve Tarihlenmesini Yeniden Ele Almak: Menedemos Argeades Adına Basılan Dodona Sikkeleri \\ Özet}

Dodona'daki tapınakta MENE $\triangle \mathrm{HMO} \Sigma$ APГEA $\Delta \mathrm{H} \Sigma$ IEPEY $\Sigma$ (RAHIP MENEDEMOS ARGEADES) adına basılan bir dizi bronz sikke bulunmuştur. Bu önemli sikkelerin ikonografisi Zeus Dodonaios ve kartalı, Artemis ve onun sembolleri (ok ve sadak) gibi geleneksel Apeiros (Epirus) baskı tiplerini yansıtmaktadır. Bunları ilk çalışan bilim insanı Franke, sikkeler için tarihsel veriler doğrultusunda İ. S. 168-148 arasını önermiştir. Bu makalede, stil, epigrafik ve metrolojik gözlemlerin antik kaynaklarla karşılaştırılması neticesinde bu sikkeler için yeni bir kronoloji sunulmaktadır. Özellikle, bu baskıların stillerinin Geç Cumhuriyet Dönemi’nde basılan gümüş denarii tiplerine benzediği görülmektedir. Zeus Dodonaios büstü, Lucius Staius Murcus'un (İ. Ö. 42-41) ilgili Roma denarius tiplerine ve Artemis'in saç tipi de Gaius Hosidius Geta'nın (İ. Ö. 68) ve temel olarak, Caesar'ı́n yandaşları olan Gaius Antius Restio'nun (İ. Ö. 47) ve Titus Carisius'un (İ. Ö. 46) gümüş sikkelerinde betimlenen Diana’nın saç tipine benzemektedir. Augustus Dönemi'nde Diana’nın bu saç tipi terkedilmiştir.

$\mathrm{Bu}$ araştırma için kafa karıştırıcı bir durum, Dodona serisinin C tipi gibi, ağır bronz sikkelerin Yunan baskılarına uygulanan sınıfsal sistemi ile ilgilidir. Burnett, Romalı subaylar Marcus Junius Brutus, Marcus Antonius ve Gaius Octavius'a atfettiği bu uygulamanın dağılımını, İkinci İç Savaş sürecinde gözlemlemiştir. Bununla beraber, Kremydi-Sicilianou, Dion’un parasal üretimini inceleyerek, Roma kolonisi Colonia Felix Diensis'in kuruluşunun arkasındaki fikir babasının - bu kuruluş onun öldürülmesinden sonra gerçekleşmiş olsa bile - Julius Caesar olduğu sonucuna ulaşmıştır. Julius Caesar tarafından kurulan diğer bir koloni de yeni para sisteminin uygulandığ Colonia Iulia Felix Sinope idi.

Dodona'daki bronz sikkelerde ethnikon görünmemesi Yunan nümizmatiğinde tekil bir durumdur. Franke, Argeades ismini Makedonya'nın kraliyet hanedanlığı ile ilişkilendirmektedir. Yazıtın yayılımı, Büyük İskender ve ardıllarının dönemlerindeki Makedonya kralları tarafından basılan sikkeler üzerindekileri anımsatmaktadır. Menedemos Argeades'in gizemli kimliği, Caesar'ın İç Savaş kitabının ve Cicero'nun mektuplarının satırlarından ortaya çıkarılabilmektedir. İç Savaşlar'ın bir bölümünde Caesar, Macedonia libera princeps'i Menedemos'a kendi müttefiki olarak referans vermektedir. Bununla beraber, Cicero Menedemos ve Petraios'un politik çatışmalardaki rollerine ilişkin çok önemli bir bilgi vermektedir. Onun anlatımına göre, her ikisi de Caesar'ın sadık yandaşları olmuşlardır ve Roma vatandaşlığı ile ödüllendirilmişlerdir. Caesar'ın otokrasisi esnasında Thessalia Birliği (strategos) Patraios adına gümüş ve bronz sikkeler basmış, Menedemos ise bu bronz sikkelerin baskılarının piyasa sürümü için Dodona Tapınağı'na para yardımında bulunmuştur. Kendisini gururla Zeus Dodonaios rahibi ve Argeades kraliyet soyuna ait göstererek döneminin anlayışını yansitmaktadir.

Onun politik etkinliği uzun sürmemiştir. Caesar’ın öldürülmesinden bir yıl sonra, Marcus Junius Brutus tarafından Petraios ile birlikte idam edilmiştir.

Anahtar Sözcükler: Roma denarius stili; ağır bronz sikkeler; ethnikonsuzluk; Caesar; Menedemos Argeades; İç Savaşlar. 


\section{Reconsidering the Interpretation and Dating of Ancient Coins: the case of Bronze Coins from Dodona in the Name of Menedemos Argeades}

Abstract

In the sanctuary of Dodona a series of bronze coins were minted in the name of MENE $\triangle H M O \Sigma$ AРГEA $\triangle \mathrm{H} \Sigma$ IEPEY $\Sigma$ (PRIEST MENEDEMOS ARGEADES). The iconography of this substantial coinage follows the traditional types struck by the Epirote mints, such as Dodonaios Zeus and his eagle, Artemis and her attributes (arrow and quiver). Franke, the first scholar who studied them, from historical events proposed a date in the period 168-148 B.C.

In this paper a new chronological date for these coins is proposed, from style, epigraphic and the metrological observations, combined with the ancient sources. Specifically, the style of these issues echoes the types of silver denarii minted during the late republican period. The bust of Dodonaios Zeus bears a resemblance to the relevant type of Roman denarii of Lucius Staius Murcus (42-41 B.C.) and the hairstyle of Artemis to Diana's as the latter is depicted on the silver coins of Gaius Hosidius Geta (68 B.C.), and mainly of Caesar's followers, Gaius Antius Restio (47 B.C.) and Titus Carisius (46 B.C). In the Augustan era, this hairstyle for Diana is abandoned.

For research, a puzzling issue concerns the denominational system of the heavy bronze coins, which were applied to the Greek mints, as the type $\mathrm{C}$ of the series of Dodona. Burnett observed the distribution of this practice during the Second Civil War, which he attributed to the Roman officers of Marcus Junius Brutus, Marcus Antonius and Gaius Octavius. Nevertheless, Kremydi-Sicilianou concluded, by examining the monetary production of Dion, that Julius Caesar was the mastermind behind the foundation of the Roman colony (Colonia Felix Diensis), although it was established after his assassination. Another colony founded by Julius Caesar, was Colonia Iulia Felix Sinope, where this new monetary system was also applied.

The omission of the ethnicon on Dodona's bronze coins is unique in Greek numismatics. Franke first linked the name Argeades to the royal dynasty of Macedonia. The extent of the inscription is reminiscent of those on the coins of the Macedonian kings from the time of Alexander the Great and his successors. The mysterious identity of Menedemos Argeades seems to unfold through lines in Caesar's Civil War and Cicero's in correspondence. In a passage in the Civil Wars, Caesar made a reference to Menedemos, princeps of Macedonia libera, as an ally of his. However, Cicero provided crucial data related to Menedemos and Petraeos' activity in political strife. According to his narration, both became intimate followers of Caesar and both were granted the privilege of Roman citizenship. During Caesar's autocracy, the Thessalian league minted silver and bronze coins in the name of (strategos) Petraeos, while Menedemos contributed financially to the sanctuary of Dodona for the emission of these bronze issues. He proudly presented himself as priest of Dodonaios Zeus and descent of the royal branch of Argeades reflecting the morale of his era.

His political activity did not continue for long. A year after the brutal assassination of Caesar, he was executed together with Petraeos by Marcus Junius Brutus.

Keywords: style of roman denarii; heavy bronze coins; omission of ethnicon; Caesar; Menedemos Argeades; Civil Wars. 


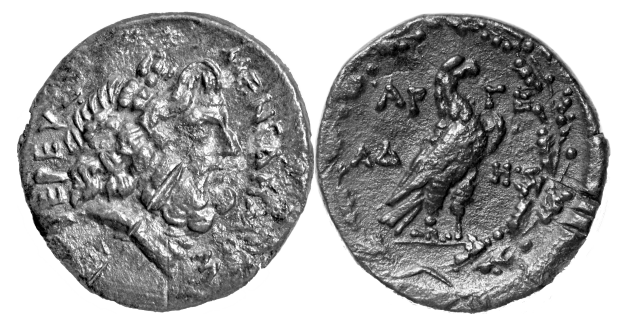

1.

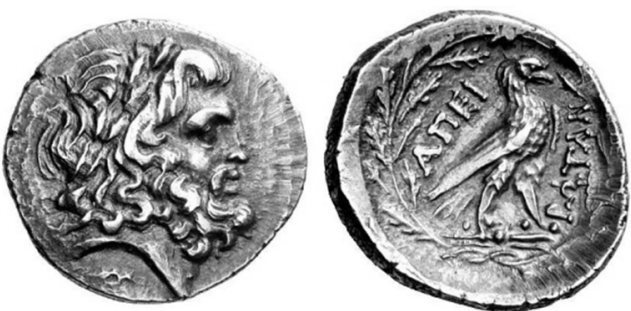

3.

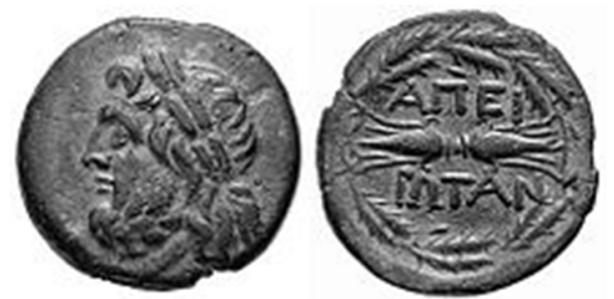

5.

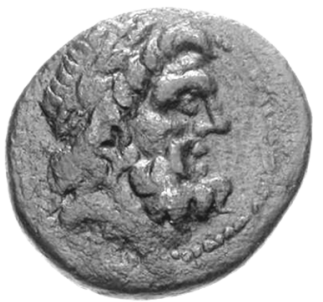

8.
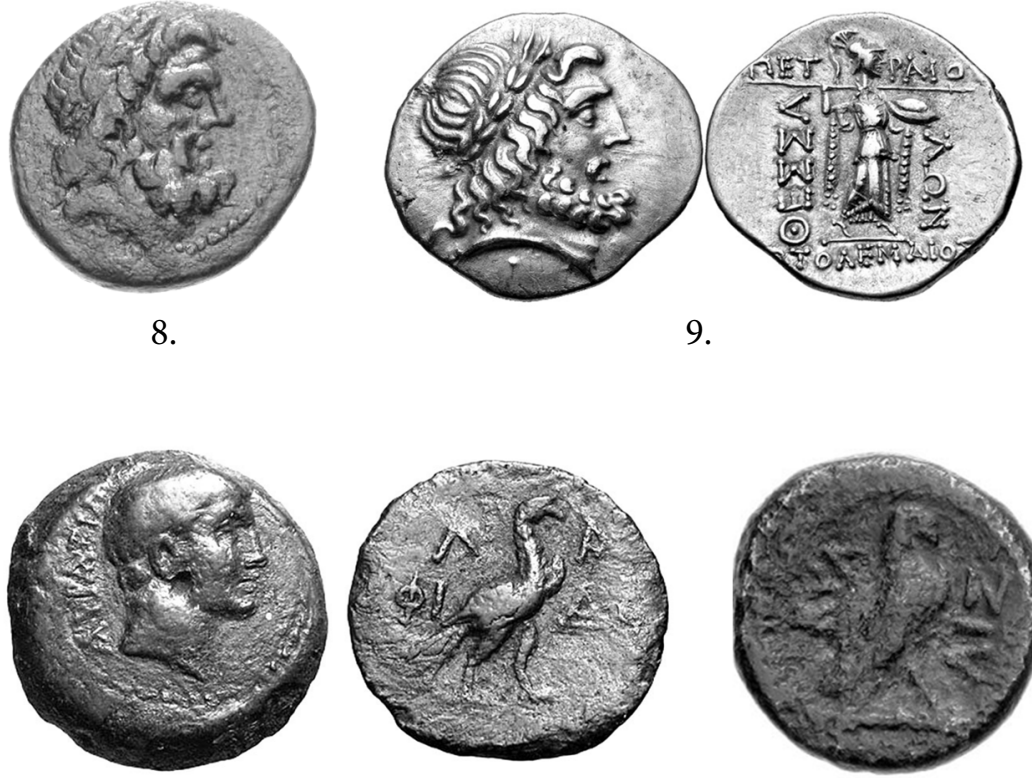

9.

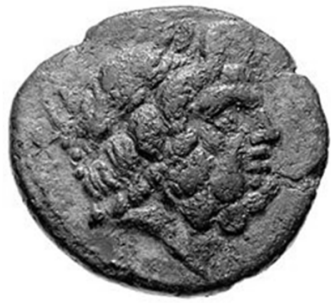

6.

7.
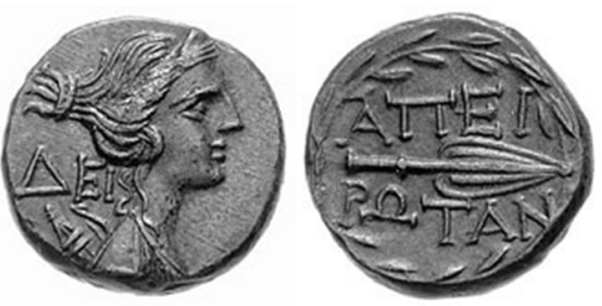

4.

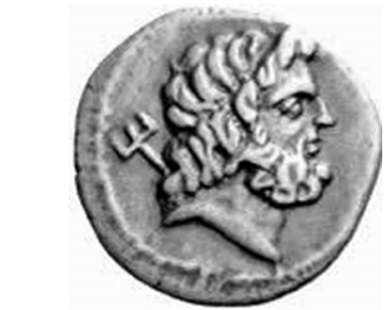

2.

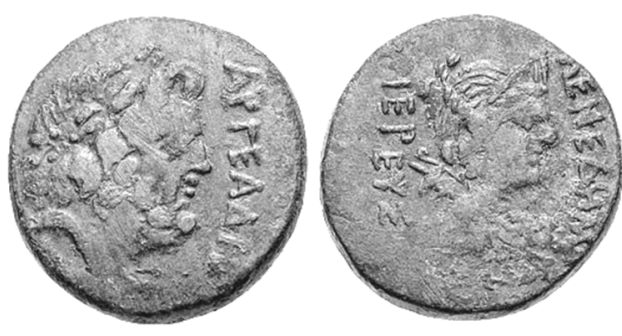




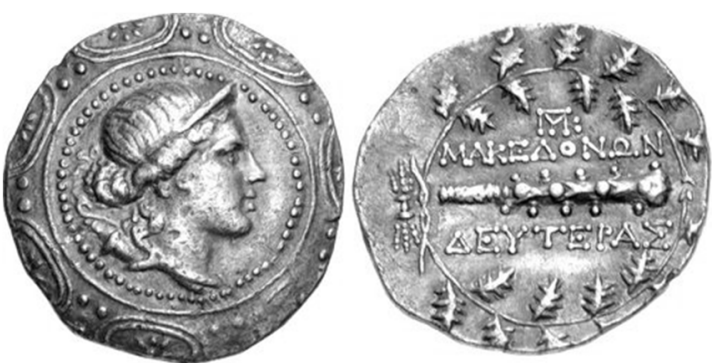

14.

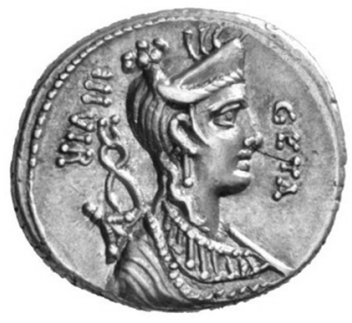

17.

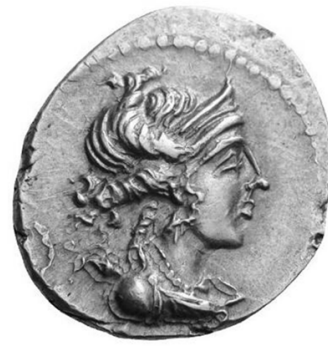

15.

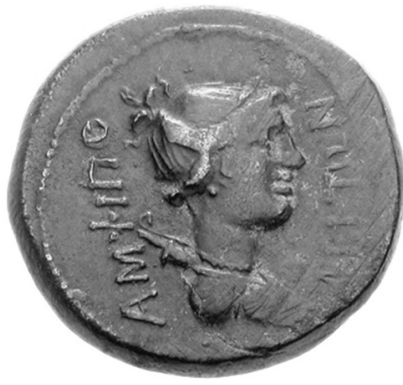

19.

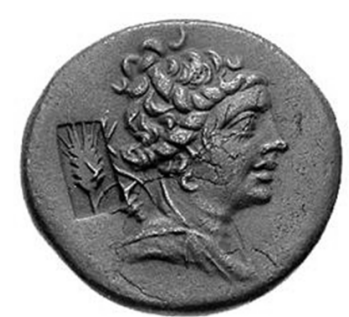

16.

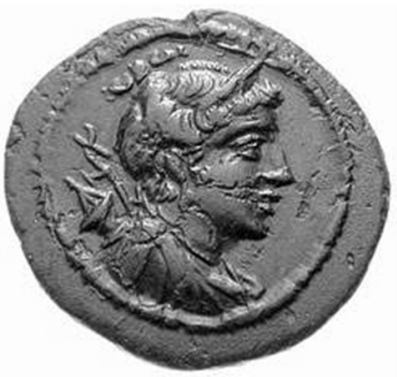

20.

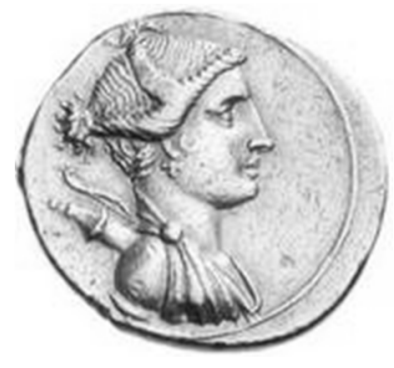

21. 